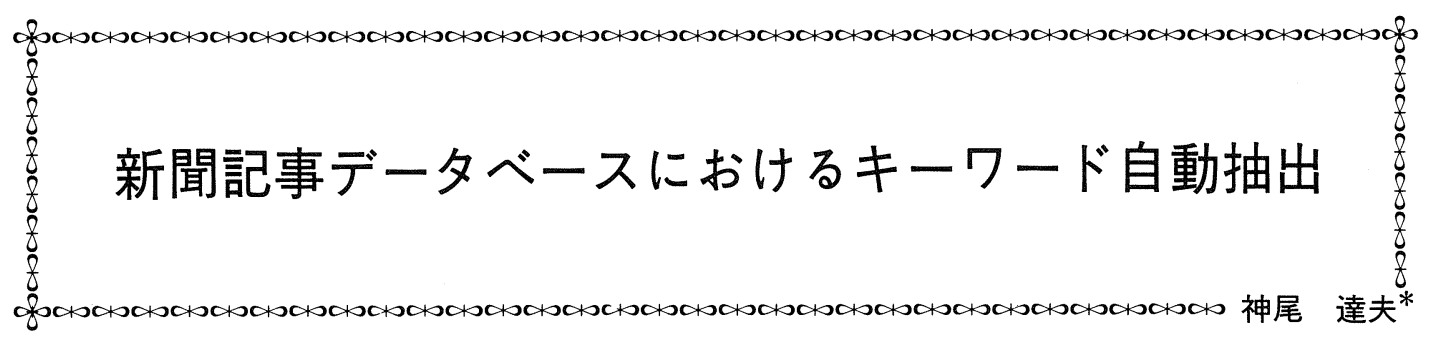

\title{
Automated indexing for making of a newspaper article database
}

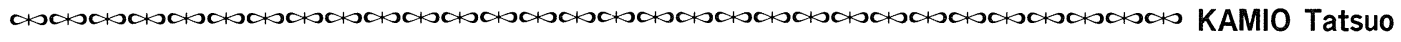

[著者抄録］＼cjkstart新聞記事データベースではキーワード自動抽出の採用が定着している。毎日， 多量の記事をデータベース化するには, コンピュータのカを借りたスピード・アップと省力化 は不可欠である。ただ, 現在実用化されているシステムによる自動抽出語は, 主題分析との関 連性がなく，厳密にはキーワードとは言えない。このため，日本経済新聞社では，新聞記事の 特性を利用して $(1)$ 抽出語の出現位置がどこか $(2)$ 記事の主題分野と抽出語のシソーラス上の 分類が一致するかの 2 点を手掛かりに，不完全ながらキーワードの判定を行っている。また， AI 技法を利用した自然言語処理によって, 記事中にないキーワードを付与する実験を行い, 好 結果を得た。

[著者付与キーワード] 新聞, 記事データベース, キーワード, シソーラス, 統制語, フリ 一ターム, 自動索引法, 人工知能, 自然言語処理

\begin{abstract}
[Author Abstract] Automated indexing has been widely employed in the process of making newspaper article databases. It is essential to speed up the compiling time of the said databases for the large amount of articles come out daily, and save manpower involved in it, with the aid of computers. However, indexed terms which are extracted by the current automated indexing systems have no links with subject analysis, so that they are not considered to be keywords in a strict sense. Thus, the system of Nihon Keizai Shimbun KK enables to justify keywords to certain extent based on the two clues ; 1) at which location the extracted term occurred, and 2) whether or not subject area of the article corresponds to thesaurus class of the extracted term, by using characteristics peculiar to newspaper articles. Also the experiment of assigning keywords which are not occurred in articles was conducted. The fairly good result was obtained.
\end{abstract}

[Keywords by Author] newspaper, newspaper article database, thesaurus, descriptor, free term, keyword, automated indexing, artificial intelligence, natural language processing

* 日本経済新聞社 データバンク局 記事情報部長（干 100-66 千代田区大手町 1-9-5) Tel.03(270)0251 Nihon Keizai Shimbun, Inc. Databank Bureau, News Information Dept. Manager

( 9 - 5, Otemachi, 1-chome, Chiyoda-ku, Tokyo, 100-66) 


\section{1. は じめに}

新聞には毎日，たくさんの記事が掲載されてい る。日本経済新聞社では日本経済新聞, 日経産業 新聞, 日経金融新聞 (以上日刊), 日経流通新聞 (週 3 回刊）の 4 種類の新聞を発行しており，これら に掲載される記事の大半（日本経済新聞の地方経 済面を含む。ただしスポーツ記事など若干の記事 を除く）をデータベース化しているが，その件数 は昨年 1 年間で 271,639 件に上っている。

これらの記事をデータベース化するために，1 件 1 件を人手で索引づけするのは容易でない。か なりの人と時間が必要になるだろう。新聞記事の 場合は，記事が掲載されてからデータベースで検 索可能になるまでの夕イムラグが, 出来る限り短 いことが要求される。現在, 記事データベースは 日次で更新され，遅くても翌日には検索できるよ うに努めている。

これを可能にしたのが, 新聞の CTS (Computer Typesetting System) 化とコンピュー夕を使った 索引づけ, 自動索引ともキーワード自動抽出とも 呼ばれる技術の開発であり, 日本経済新聞社をは じめ朝日新聞社, 読売新聞社など記事データベー スをプロデュースしている新聞社では, コンピュ 一タによる索引づけを実用化している。

本誌の読者諸兄姉には, 自動索引は目新しい話 題ではないと思われるが, 新聞記事データベース にとっては不可欠の技術であり, 急速な研究開発 がぜひとも望まれる。本稿では記事データベース における索引の特性とキーワード自動抽出の現状 を日本経済新聞社の例を中心に概観し, 自然言語 処理による索引づけの可能性を考察した。

\section{2. 新聞記事の特性と索引づけ}

新聞記事は, 一般の文献と比較して文章がかな り短いのが最大の特徵である。新聞による違いも あるが大体は 1,000 字以内, 平均 700 800 字と見 られる。古い資料で恐縮だが，1982 年 $1 \sim 3$ 月の 日本経済新聞および日経産業新聞についての調査
では,この 2 紙に掲載された 23,671 記事の平均の 長さは 723.88 文字だった（ついでだが，漢字の含 有率は約 $44 \%$ \%゙った。一般には 30〜35\%が読み 易い文章とされている)。文章が短いだけに簡潔さ が尊ばれ，重要な事柄や結論的な内容を記事の冒 頭に記述するなど,独特のス夕イルを持っている。

\section{1 記事の主題要素}

古くから新聞記事に必要な要素として $5 \mathrm{~W} 1$ H (WHO, WHEN, WHERE, WHAT, WHY, HOW)が言われている。情報検索の観点から見る と, これらは索引づけが必要な主題要素であり, 日経の記事データベースでは, 新聞記事に付与す べきキーワードとして以下の 7 種類を設定してい る。

(1)会社キーワード：国内外の企業の名称。

(2)団体キーワード：国内外の各種の団体・組織 など企業以外の法人の名称。

(3)人名キーワード：記事に登場する国内外の個 人名。

(4)業界キーワード：「繊維業界」等のようにある 業種全体を指す。

(5)品目キーワード：原材料・素材, 半製品, 部 品, 完成品など製品名を中心に製法や工法, 技術，情報，サービス，レジャー，スポーツ， 組織や施設, 自然物, 学術, 職業など幅広い 範囲の用語を含む。

(6)項目キーワード : 行為, 状況, 関係等のほか, 制度，法律，政策などに関する用語。企業や 団体等の活動状況, 政治・経済・産業・社会・ 国際の動向や状況を表現する。

(7)地域キーワード：国内外の地域名。

これらの内, (1)〜 (4)は $5 \mathrm{~W} 1 \mathrm{H} の \mathrm{WHO}$ (また は WHOM)を表現するキーワードである。ニュー スの古典的な定義として,「犬が人を嚙んでも二ュ 一スではないが，人が犬を嚙んだらニュースだ」 と言われるが, 新聞記事では「だれが」「だれに(ま たはだれを)」は重要なキーワードになる。特にビ ジネスユースの検索では経済活動の主体である企 業名は最もよく使われている。 
また，(4)〜(7)は統制語になっており，日経シソ 一ラス (1988 年版)には 15,434 語が収録されてい る(図 1 )。この内で，新聞記事の索引づけの特徵 であり最も苦労しているのが，項目キーワードで ある。政治，経済，産業，社会のさまざまな現象， 政府や企業の行動，業界の動向など抽象的な概念 を的確な用語で表現するのは，なかなかむずかし い。文章中にキーワードが現れないのも普通であ る。

以上 7 種類のキーワードの外に，統制語にない 特定的な表現や新語を表す自由キーワードやフリ ーターム方式も併用している。自由キーワードは 統制語を補完する意味で「補助キーワード」と呼 んでいる(図 2 )。

これらのキーワードはキーワード辞書ファイル に収録され，日々に新しい言葉が追加されており， 現在は 30 万語を超えている。その大半の話は企業 名などの固有名詞である。

文章中から機械によって抽出され不要語を削除 した自動抽出語をキーワードにする方法は，記事 データベースではフリータームとか自由語とか呼 ばれている。フリーターム方式では，従来からキ 一ワード付与に不可欠だった主題分析の過程が省 かれているため，抽出された語の中には記事の主 題に係わる重要語とそうでない語が一緒に含まれ ている。たとえ，その語が一国の首相を表してい たりシソーラスに収録されている統制語であって

\begin{tabular}{|c|c|}
\hline \multicolumn{2}{|c|}{ 情報・通信一般 —小分類 } \\
\hline 情報 (品) —カテゴリー & · 中古車情報 \\
\hline ・イベント情報 & ・統計情報 \\
\hline ○医療情報 & ・投資情報 \\
\hline ・海外情報 & ・・株式情報 \\
\hline ・・カントリーリスク & ・・債権情報 \\
\hline 情報 & ・ファッション情報 \\
\hline • 価格情報 & • 不動産情報 \\
\hline ·画像情報 & ・・住宅情報 \\
\hline
\end{tabular}

図 1 日経シソーラス(例)

\begin{tabular}{|c|c|c|}
\hline 情報医 & シ柿柿1 & 84.09 \\
\hline 情報委員会 & ザ矤枋イイ㑃 & 84.11 \\
\hline $\begin{array}{l}\text { 商法違反 補助 } \\
\text { 寈報化 } \text { キーワード }\end{array}$ & 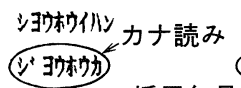 & 84.06 \\
\hline 商法改正 & 注枋力化採用年 & 85.04 \\
\hline 情報化基盤整借法案 & 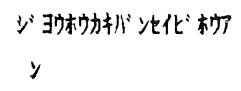 & 84.08 \\
\hline 情報化組合 & シ侨枷加三人 & 85.01 \\
\hline 情報化月間 & 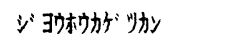 & 82.05 \\
\hline 情報化未来都市建設構想 & 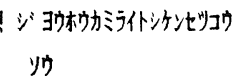 & 86.09 \\
\hline 消防官 & 淤末゙功 & 85.09 \\
\hline 情報管理士 & 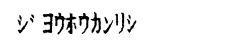 & 85.07 \\
\hline
\end{tabular}

\begin{tabular}{|c|c|c|c|}
\hline & 「異業徝交流グルーフ」 & 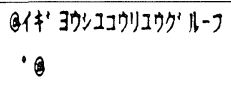 & 84.11 \\
\hline & 「界策程飛蹋へ交流」 & 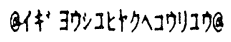 & 83.10 \\
\hline & 「異見同見」 & 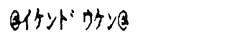 & 83.10 \\
\hline コ & 〔いす」 & 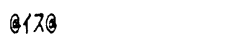 & 77.04 \\
\hline & 「一缕一見」 & 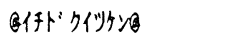 & 85.04 \\
\hline 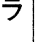 & 「一枚のスケッチから」 & 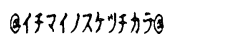 & 86.09 \\
\hline & 「一䦓一答」 & 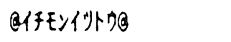 & 82.01 \\
\hline & 「1分ゼミナール」 & 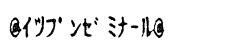 & 86.06 \\
\hline & 「異能軽営者」 & 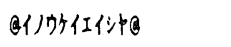 & 83.11 \\
\hline & 「 i fの世界」 & (617)㘦体 & 86.06 \\
\hline & 「異变名溥造杽」 & 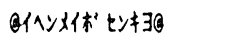 & 83.06 \\
\hline
\end{tabular}

\begin{tabular}{|c|c|c|}
\hline ○出版 & シリコルンン & 86.07 \\
\hline ○首都圆 & 叭快 & 86.07 \\
\hline ○商社 & 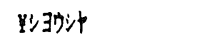 & 85.08 \\
\hline ○商社問屋 & 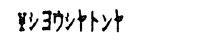 & 77.04 \\
\hline ○商社・問屋 & 里泫シ中.トン中 & 82.09 \\
\hline ○商店 & 将羽テン & 82.10 \\
\hline 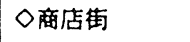 & 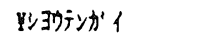 & 81.10 \\
\hline ○商店経営 & タン羽テンケ代イ & 77.04 \\
\hline ○商店・商店得 & 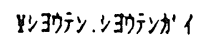 & 77.04 \\
\hline ○商店チェーン & 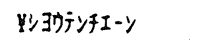 & 84.10 \\
\hline ○商店ニュース & 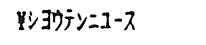 & 81.10 \\
\hline ○消零最前的 & 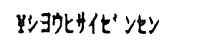 & 84.10 \\
\hline ○消費者 & ツリ㸟ミや & 77.04 \\
\hline
\end{tabular}

図 2 日経・補助・コラム・記事分類キーワード(例) 


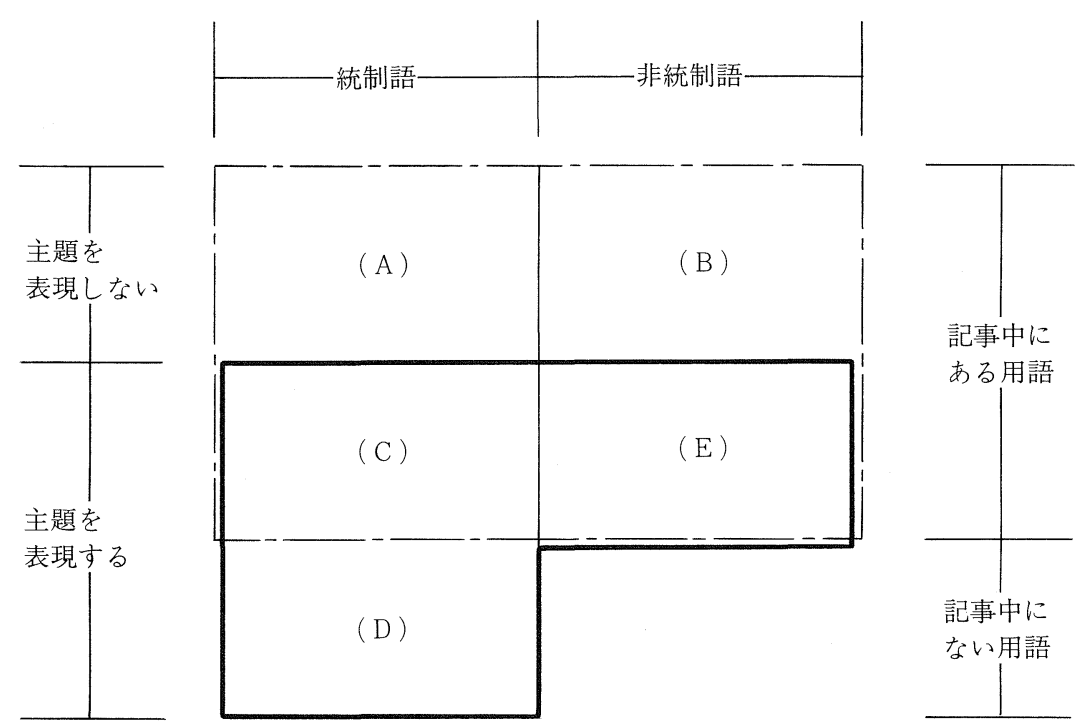

（A）シソーラスにある用語だが，記事の主題に係わりのない語。

（B）記事の主題に関わりのない固有名詞など。

(C)，（D）統制キーワード。（D）は人手で付与。

(E) 記事の主題に係わりのある固有名詞や自由キーワード。

図 3 キーワードとフリータームの概念図

太線で囲まれた部分がキーワード

一点鎖線で囲まれた部分がフリーターム

も, 記事の主題と係わりのない語をキーワードと 呼ぶのは，従来の定義では誤りだろう。また，記 事の主題を的確に表現する語が文章中にない場 合，フリータームとしては現れてこない。新聞記 事の場合は「技術交流」とか「省エネルギー」と か, 私達が項目キーワードと呼んでいる語で表現 される主題が重要であり, これらの語が文章中に ない時は人手で付与する必要がある。(図 3 )。

\section{2 記事の連続性・関連性}

論文などの文献は内容が首尾一貫しており，そ れ自身で完結し，独立している。これに比べ新聞 記事の場合は, 文章も短く, その内容は悪く言え ば断片的である。新聞が 1 日あるいは半日単位で 最新の動向を伝えねばならない役割を負っている 以上，避けられない。事態の推移に応じて「続報」
が揭載されるが，報道済みの事柄は「周知の事実」 として省かれ, 新しい情報だけを報じる事も多く, 1 件の記事を読んだだけでは出来事の全容が摑み にくい。毎日のニュース記事一つ一つは「ジグソ 一パズルの一片」であり，「全体を見るには組み立 て」る必要がある（読売新聞記事データベース 「YOMIDAS」のパンフレットより)。

新聞情報の検索では目的の記事 $1 ， 2$ 件を探す ことより，あるテーマに係わる記事をもれなく一 網打尽にして, テーマ全体の動向を把握したり傾 向を分析することがしばしば行われる。このよう な新聞情報の検索では，一連の事件の記事や関連 性のある記事がまとまってヒットすることが要求 される。

日経では, 1975 年に記事データベースの作成を 開始して以来，検索もれを最小限にするため，一 
貫して統制語を主体にし，自由キーワードやフリ 一タームを補完的に用いている。また，連載企画 記事や一連の関連記事に共通のキーワードを決め て，索引づけしているのもこのためである。

\section{3 自動抽出への適応性}

新聞記事にはキーワード自動抽出に有利な特性 が幾つかあげられる。

（1）重要な事柄から書き出す形式であること。 新聞記事は見出し，前書き（前文という）， 本文という構成になっている。見出しは記事 のエッセンスを短い文で表現する。また，重 要な事柄はすべて前文に書くのが鉄則であ る。したがって見出しや前文には，記事のキ ーワードとなり得る重要語が多く含まれてい る。

文章が短く簡潔さが尊ばれることから, 繰 ク返しを嫌い，「同社では」とか「同計画によ れば」などと省略して表現される。したがっ て，重要語が反復して出現する事も少なく， 頻度分析によるキーワードの重要度判定には 向かない文章に思える。

（2）用字・用語や表記法が統制されていること。 ほとんどの新聞社では「スタイルブック」 （ファッションではなく文章のスタイル）や 「用字用語集」などの名称のハンドブックを作 成している。ここにはさまざまな言葉の表記 法，かなづかい，言葉の言い換えなどが規定 され，記事を書く際の典拠になっている。こ れが $100 \%$ 守られているとは言い難いが，記 者が書いた原稿がデスク，整理記者，校閲記 者と何人ものチェックを経ていくうちにス夕 イル違反が是正される。したがって自動抽出 のプログラムはこのルールに則って，文の解 析を行えばよい。

\section{3. 自動抽出の手法}

ベ夕書きの漢字かな交じり文章を分かち書きし て不要語を削除し，読みがなを与えるキーワード
自動抽出または自動索引の手法についてはさまざ まな文献があり，ここでは多言を要しない。侏平 和情報センターの HAPPINESSのような汎用の ソフトウエアも販売されている。

\section{1 複合語の処理}

キーワード自動抽出では複合語の処理が問題に なる。ここで言う「複合語」は「本箱」のように 「本」と「箱」という二つの最小有意義単位（形態 素)からなっている単語ではなく,「日米貿易摩擦」 や「情報検索システム」のように複数の単語が連 結した複合的な語を指している。

「日米貿易摩擦」のような語が記事中から抽出さ れた場合，同時にこの記事が「日米貿易」や「貿 易摩擦」でもヒットする必要がある。日米／貿易／ 摩擦と単語に分解して隣接演算子を使用したり, 前方一致・後方一致を行えば可能だが，記事デー タベースの利用者にはより簡単な操作が必要であ る。

そこで，単語に分割するだけでなく，隣合った 複数の単語を組み合わせて，新しい語を合成する 措置が取られている。あるキーワードが $\mathrm{A} \cdot \mathrm{B} \cdot \mathrm{C}$. $\mathrm{D} の$ 四つの単語からなっていれば，ここから得ら れる語は，ABCD (その語自身) と各構成要素の $\mathrm{A}, \mathrm{B}, \mathrm{C}, \mathrm{D}$ の外に $\mathrm{AB}, \mathrm{ABC}, \mathrm{BC}, \mathrm{BCD}, \mathrm{CD}$ の計 10 個になる。

特に新聞記事では(簡潔さを重視して?)「てに をは」が省略され，漢字やカタカ十の長い文字列 が出現する事が稀でない。「ベトナム援助軍司令部 設置以来約二十年」のように 18 文字の例もあり， 複合的な用語の分割は不可欠である。

\section{2 自動抽出の実例}

朝日新聞社では，記事データベース「HIASK」 の作成に日本 IBM の JDPS（日本語文書処理シス テム) を基本にして開発したシステムでキーワー ド抽出を行っている。このシステムではべ夕書き の漢字かな交じり文を解析，全文をカ夕カ十書き に変換したあとで，その中の名詞をキーワードと して抽出する。複合語は分割され，隣接の語を組 
み合わせて, 複数のカタカナ・キーワードを作成 する。抽出される語数が多くなるのを防ぐために キーワード抽出の対象とする文章の範囲を記事ご とに指定し，自動抽出の結果には手を加えない。 読売新聞社の「YOMIDAS」の作成には HAPPINESS が使われている。見出しと記事の先頭 400 字から最大 72 語の索引語を抽出, 複合語の分 割・合成は 3 単位を限度に行っている。機械処理 の結果は記事単位で「編集指示書」と呼ばれるリ ストに出力され, 編集担当者が点検して, タイト ル（見出し）の修正, 索引語の削除と追加, ふり がなの修正等を指示し，端末で修正している。

\section{3 フリータームの補完}

文章中から機械的に抽出され，不要語を除いた だけの索引語は，厳密にはキーワードとは言えな い。主題分析の結果, 主題を表現する語として文 章中から抽出されたり，シソーラスの中から選ば れて付与されるキーワードと, フリータームの名 で呼ばれる自動抽出語とは本来，別物である。た だ，前述したように新聞記事の場合は，見出しあ るいは前文を対象にしたり，重要語が多く含まれ ている特定の箇所を事前に指定して抽出すれば, これをそのまま索引語としても，ノイズが多くて 使いものにならないという事態は避けられるだろ う。むしろ，問題はフリータームを使用する事に よる検索もれにある。

フリータームは「思いついた言葉で検索出来る」 のがキャッチフレーズである。このために，フリ ータームは統制語よりも検索が簡単と誤解する向 きもあるようだ。フリータームだけで過不足なく 検索をするには同義語の存在など若干の注意が必 要だし, 特に抽象的な概念の検索では相当高度な テクニックを要する。

簡単な例を上げると，「火事」の記事を探すため にそのまま言葉をいれても必要なものがヒットす るとは限らない。記事中では「出火」とか「焼失」 などの具体的な表現はあっても，意外に「火事」

の言葉は少ない。

朝日新聞社の「HIASK」はフリータームが主体
だが，検索もれとノイズを防ぐために「分類」（用 語と数值コード）も人手で付与している。「分類」 は一種の統制語で，3段階に階層分類された 1,063 語 (主題分類 835 語, 国別分類 219 語, 記事 種別分類 9 語) の「ミニ・シソーラス」を形成し ている。フリータームから「分類」を参照する辞 書も作成している。

読売新聞社でも，フリータームの欠陥をカバー するため「管理語辞書」を作成している。ここに は辞書の見出し語に該当するリード・タームに対 して，その同義語，狭義語，関連語が収録され， 定期的に更新されている。1987 年末現在でその数 はリードターム 8,400 , 同義語 7,300 , 狭義語 6,000 , 関連語 9,700 となっている。

\section{4. 日経における自動抽出}

日本経済新聞社では，自動抽出を採用する以前 から, 統制語を主体に自由キーワードを併用して, インデクサによる主題分析 ーキーワード付与を行 っており，この過程を省力化する事を目標に自動 化を進めてきた。残念ながら現在の技術レベルで は解決困難な問題が多く, 高度なシステムとは言 いがたい。自動抽出後にインデクサの点検に依存 するところがまだ多く，「キーワード」抽出の精度 をいかに高めるかが最大の課題である。

自動抽出システムは 1984 年に稼働を開始, その 後改良を重ねて現在に至っている。1986 年からは 主題にかかわりのない語も索引語にするフリー夕 一ム方式も導入している。

キーワード自動抽出の過程は (1)キーワード候 補語の抽出，(2)キーワードの判定，(3) 統制語の 追加付与一一ら成っており, 以下にその概要を 記述する(図 4 )。

\section{1 キーワード候補語の抽出}

見出しおよび前文（記事の冒頭の 200 400 字) を対象に, 字種の相違に着目するとともに, 単語 テーブルなど各種のテーブルを参照して名詞を抽 出, 不要語テーブルに収録された用語を削除する。 


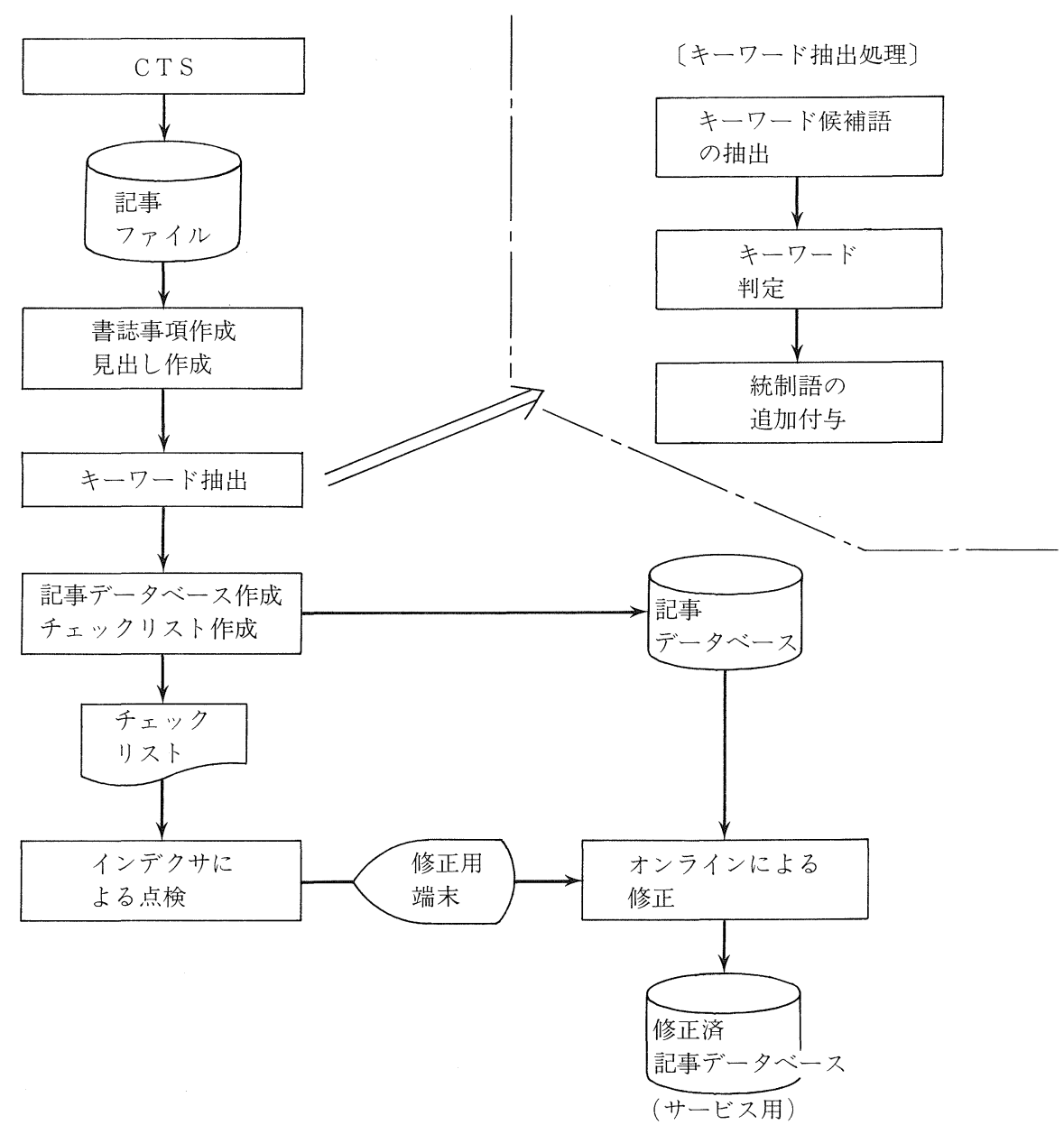

図４日経における記事データベース作成処理

不要語には 2 種類あり，通常キーワードになり得 ない語（野党側，石油危機以来など本来のストッ プワード）と単独ではキーワードにならないが複 合語の一部としてキーワードになり得る語（日米 関係，教育問題など）がある。また，「力ギを握る」 の「カギ」のような新聞記事の常套語も不要語テ 一ブルに収録している。数值はすべて不要語と見 なして削除する。

複合語は単語に分割して，「3．1」で述べた原則 に従って合成語を作る。ただし，キーワード辞書
ファイルを参照して企業名, 人名等と判定された 語は分割しない。特にカタカ十語の分割は注意し ないと「ワインバーガー」や「チャイコフスキー」 から「ワイン」や「スキー」が分離されるおそれ がある。

\section{2 キーワードの判定}

前述の処理で抽出された単語, 複合語, および 合成語をキーワード候補語として以下の 2 段階の 判定を行う。 
(1) 一次判定

キーワード辞書ファイルを参照, ファイルに登 録されている語が一次判定をパスする。パスしな かった語は記事単位でリストアップして，その採 否はインデクサの点検に委ねられる。

ここで，時々問題になるのが固有名詞（特に企 業名）の判定である。企業名の中には普通名詞と 同一のものがあり，機械による判定ではいずれと も決められない。また, 同名の企業も多く, 誤っ て索引づけられる事態も生じる。

日経の記事データベースでは同音語に識別子を 付したり, 同名企業はカッコ書きで業種, 所在地 等を記述している。記事データベースの主力検索 サービスである「日経ニュース・テレコン」では, 同音語・同形異義語はディスプレイに表示して選 択する機能を有している。このような固有名詞の 処理も今後の課題である。

(2) 二次判定

一次判定をパスした語で次の二つの基準のいず れかに合致したものが，最終的にキーワードと判 断される。

(1)抽出位置による判定：判定の対象となる語が 見出し, 記事本文のどの位置（何番目のセンテン スか）から抽出されたかによって判断する。例之 ば，見出しから抽出されていればキーワードにな り得るし, 記事の第 1 センテンスに出現する固有 名詞は重要語と判断して差し支えないだろう。

(2)記事の主題との一致：判定の対象となる語が シソーラスに載っている統制語の場合, シソーラ ス上の分類と記事が扱っている主題分野が一致す ればキーワードとみなす。新聞は政治面, 経済面 のように面別に編集され, 特に日経産業新聞は産 業毎に紙面が分けられているので, 大まかな主題 分野を与えることができる。今では笑い話だが, この機能を付加する以前, 住宅関係の記事から「う なぎ」のキーワードが抽出された事があった。「住 宅着工件数がうなぎ登り」の記述のためだった。

以上の結果, 非キーワードと判定された語も索 引語として残される。内部ではこれを「フリータ 一ム」と（図3の定義からは明らかに䛊用である
が）称している。

\section{3 統制語の追加付与}

キーワードと判定された語から必要に応じて, 統制形または統制語を追加付与する。統制形とは 企業名, 団体名, 人名の定められた表記法である。 「竹下前首相」からは「竹下登」が付与される。ま た，前述のとおりシソーラスにない自由キーワー ドは「補助キーワード」と呼んでいるが, 補助キ ーワードと統制語を対応づけたファイルがあり (親子ファイルと呼称)，これを参照して統制語を 付与する。「親子ファイル」の対応関係は同義の他 に次のものがある（例はいずれも左が補助キーワ ード)。

(1)「補助」が統制語の下位語であるもの。

(例) LNG 火力 : 火力発電

(2)上位下位の関係にはないが，検索上密接な関 連があるもの。

(例) 放映権：映画

(3)補助」の概念を複数の統制語で表現できるも の。

(例) $\mathrm{AF}$ 一眼レフカメラ：一眼レフカメラ, 自動焦点カメラ

「親子ファイル」には, 現在約 10,700 語がエン トリーされている。統制語の付与に威力を発揮す るためには, 少なくとも数万語のレベルに達する 必要があり, 毎日追加更新しているが, 対応づけ がむずかしく増やすのは容易でない。

これらの過程は, 朝刊の最終版終了後の午前 2 時過ぎからコンピュー夕処理される。平均 800 件 近い記事を処理するのに 1 ～2 時間を要する。

\section{4 インデクサによる点検}

自動抽出の結果は, 記事単位でプリンタに出力 され，インデクサによる点検・修正が行われる。 主な作業は見出しの修正, キーワードの追加・削 除である。CTSの記事ファイルから自動作成した 見出しのうち, 修正が必要なものは 20 30\%であ る。キーワード自動抽出の結果は会社キーワード や品目キーワードの精度が高いが, 項目キーワー 

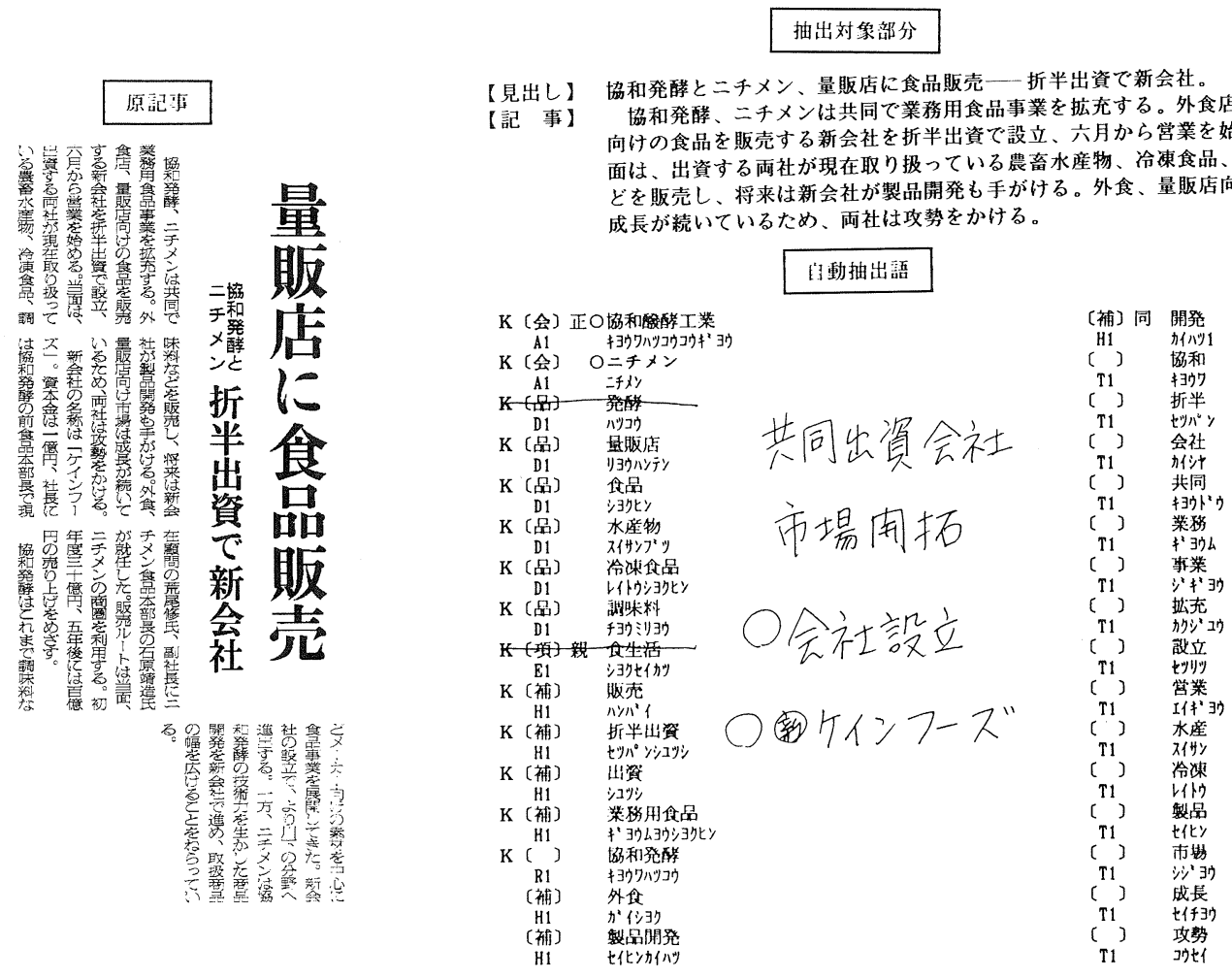

図 5 日経における自動抽出語とインデクサの点検結果の例

(注)語の前に「K」とあるのがキーワード。また「正」は同義語

や企業の略称の統制形。「親」は親子ファイルで付与された統制語。

ドは低い。インデクサの作業は項目キーワードの 追加が中心になっている(図 5 )。

\section{AI を利用したキーワード付与の実験}

以上のようにキーワードの判定は頻度分析も構 文解析も用いず，新聞記事の特殊性を利用した安 易な方法である。むろん，その精度には不満があ るが，問題は非キーワードがノイズとして紛れこ むことでなく,キーワードとして抽出できない語, つまり文章中に現れないキーワードをいかに「付 与」するかであり，AI 技法を使用した自然言語処 理によって，その一部分をカバーできないかと考
えている。

\section{1 記事にない語の付与}

自然言語処理によって文章中にはないキーワー ド（シソーラスの統制語）が導き出せるケースと して次の 3 例が想定される。

(1)文章中にキーワードの一部分が存在する場 合。例之ば「開発」という語があれば，これに 文脈上関係ある言葉から「資源開発」「地域開発」 などのキーワードを導き出す。

(2)文章中にキーワードの構成要素が離れて存在 する場合。例えば「共同で養殖事業に乗り出す」 の文から「共同事業」を付与する。 
(3)キーとなるいくつかの用語から類推できる場 合。例之ば「開発」「商品化」「発売」などの用 語が文脈上の関連が得られれば「新製品」のキ ーワードを付与する。

日本経済新聞社ではこのうち，(3)の仮説を検証 するため，株十印および日本ディジタル・イクイ ップメントの協力を得てごく小さな実験用のプロ グラムを作成した。プログラム言語は LISPであ る。

\section{2 実験の内容と結果}

実験では，付与すべきキーワードとして，最も 簡単と思われる「人事」を選んだ(図 6 )。

人事記事は通常, 以下のような基本文型で記述 される事が多い。
(1) $\mathrm{A}$ 社は**日の取締役会で副社長の B 氏 (または B 副社長) を社長に選任した（または選 んだ)。

(2) $\mathrm{A}$ 社は**日の取締役会で $\mathrm{C}$ 社長の会長就 任と，その後任に，B副社長の昇格を内定した。 (3) $\mathrm{A}$ 社の $\mathrm{B}$ 専務は**日付で社長に昇格す る。

ここで，キーになる言葉は，A 社のような企業 名・組織名 (固有名詞), 社長・副社長のような地 位を表す名詞，選ぶ・選任・昇格のような動詞， および「する」をつけて動詞化される名詞，これ らを関係づける格助詞である。

そこで，人事に関係のある名詞，動詞，助詞を 選んでミ二辞書を作成，動詞にはそれがどのよう な格パターン（行為者格，対象格，目標格）を持

【例文】雪印乳業は十九日開いた取締役会で鈴木常正副社長 (67) を代表取締役とするとともに社 長代行に選任した。

（1）動詞「選任」について, 辞書の内容は右の通り。

（2）表層格（助詞）を手掛か りにして得られた深層格 （行為者格，対象格，目標 格）の格要素の内容は右 のようになっている。

（3）各深層格に対応する属性 值をルールにあてはめる とルール 2 に適合する。

\begin{tabular}{|c|c|c|c|c|c|c|c|}
\hline \multirow{2}{*}{\multicolumn{2}{|c|}{ 見出し語 }} & \multirow[t]{2}{*}{ 品詞 } & \multirow[t]{2}{*}{ 分類 } & \multirow[t]{2}{*}{ 意味 } & 深 & 層 & 格 \\
\hline & & & & & 表 & 層 & 格 \\
\hline \multirow{2}{*}{\multicolumn{2}{|c|}{ 選任する }} & \multirow[t]{2}{*}{ 動詞 } & & & 行為者格 & 対象格 & 目標格 \\
\hline & & & & & が/は & を & に \\
\hline 助詞 & & 格 & & 名 詞 & \multicolumn{2}{|c|}{ 属性值 } & \\
\hline r & \multirow{2}{*}{\multicolumn{2}{|c|}{$\begin{array}{l}\text { 目標格 } \\
\text { 対象格 }\end{array}$}} & \multicolumn{2}{|c|}{ 社長代行 } & \multicolumn{2}{|c|}{ 属性，地位 } & \\
\hline 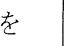 & & & \multicolumn{2}{|c|}{ 副社長 } & \multicolumn{2}{|c|}{ 属性, 地位 } & \\
\hline は & \multicolumn{2}{|c|}{ 行為者格 } & \multicolumn{2}{|c|}{ 雪印乳業 } & 固有, & 組織 & \\
\hline
\end{tabular}

【ルール2】媣層格「行為者格」に対応する格要素が属性值「固 有」「組織」を持ち

AND

深層格「対象者」に対応する格要素が属性值「属 性」,「地位」を持ち

AND

深層格「目標格」に対応する格要素が属性值「属 性」,「地位」を持つなら

キーワード「人事」を付与せよ。

図 $64 \mathrm{AI}$ 技法によるキーワード付与 
つかを記述し，名詞には固有・組織・地位などの 属性值を与えた。また，上記の基本文型から二つ のルールを作成した。

処理の概要は次の通りである。

(1)記事の第 1 センテンスの動詞に着目し, 辞書 からその格パターンとそれに対応する助詞（行 為者格なら「が」または「は」）を見る。

(2)それぞれの格要素の属性值を見る。

(3)ルールにあてはめ，いずれかにマッチすれば キーワード「人事」を付与する。

このプログラムはプロトタイプにも達しないミ ニユニットであるが，数件の記事で検証した結果 は良好だった。本格的な検証をするには，少なく とも数千件の記事を対象にする必要があるが，そ れには企業名を中心に辞書の大幅な拡充が不可欠 であり，現在その作業を進めるよう検討中である。 辞書を充実させルールを増やしていけば，「人事。 だけではなく「新製品」等，特定のキーワードの 付与が実現できる見通しが強い。

自動抽出した索引語の重要度判定を文章解析で 行うことは, 自然言語処理の一部として研究され, NTTデー夕通信などが，商用化ソフトを作成し ている。同時に，新聞記事など特殊な文では，文
章中にないキーワードを付与することも，一定の レベルや分野の用語なら困難ではないと見られ る。今後の研究に期待するところが大きい。

\section{6. おわりに}

新聞記事データベースの構築・商用化が進むに つれ，データベース利用者の裾野が広がっている。 新しい利用者層は情報や技術分野の専門家でな く，一般のビジネスマンである。これらの利用者 からは「思いついた言葉で検索」して過不足なく 必要な情報が得られることが要求されている。

キーワード自動抽出は大量の情報を，人件費な ぞのコストを極力抑えつつ短時間で処理したいと のプロデューサ側の必要性から求められている が，この研究開発から得られた成果には，使い勝 手のよい検索システムの開発に役立つものが少な くない。自然語と統制語の対応ファイルの完備や 自然言語処理の発展によって，思いついた言葉や 曖昧な言葉から，利用者が意識することなく適正 な検索語や検索式に導かれることが，今後のデー タベースの普及に不可欠であり，この方面での進 展も期待している。

\section{参 照 文 献}

1）神尾達夫。CTS を利用した新聞記事の画像デー タベース作成。情報管理。31(11)933-941(1989)

2）日経シソーラス。日本経済新聞社。(1988)

3） HAPPINESS キーワード自動抽出システム概 説。平和情報センター，(1984）

4）石井健一. 新聞記事デー夕からキーワードを自動 抽出する試み。ドキュメンテーション研究。 33(11) 543-548(1983)

5）細野公男。講座・インデクシングの方法 ( 8 ) 自動 索引。情報の科学と技術。39(4)125-131(1989)

6）斉藤裕。特集・データベースと新聞——朝日新聞 記事データベース「HIASK」。新聞経営，第 96 号，
(1986)

7） JDPS 文書検索プログラムプロダクトサマリー。 日本 IBM。

8）日本語キーワード自動抽出プログラム(AJAX) プロダクト概要。日本 IBM.

9）読売新聞社データベースプロジェクトチーム。全 方位記事データベース YOMIDAS について。新聞 印刷技術。No. 121.p 39-45(1987)

ただし，最新の数字は以下を参照した。 小田信生。読売新聞記事データベース・YOMIDAS (HAPPINESS 事例発表一II) 